\title{
Teaching NeuroImages: Cranial neuropathies following clival infarction
}

Jeremy Wong, MD, MEng, * Claudia Gambrah-Sampaney, BA, * and Laura Adang, MD, PhD Neurology ${ }^{\circledR}$ 2019;93:e1031. doi:10.1212/WNL.0000000000008070
Correspondence

Dr. Adang

adang|@email.chop.edu

Figure MRI findings of clival infarction
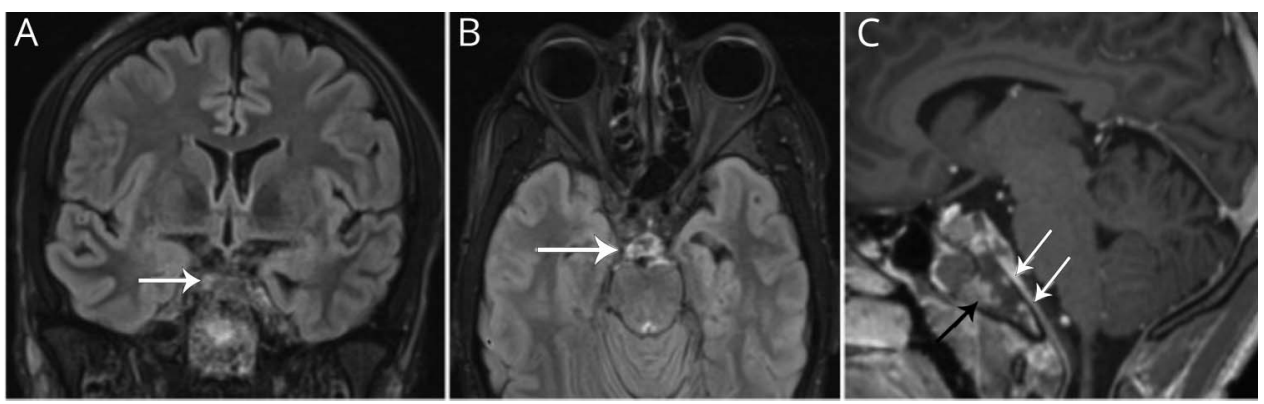

T2 FLAIR MRI sequences reveal heterogeneous edema throughout the clivus (A, B, arrows) with prominence of the retroclival dura and asymmetric thickening ( $C$, arrows). $T 1$ postcontrast imaging demonstrates heterogeneous areas of enhancement within both the bone ( $C$, black arrow) and dura $(C$, white arrows).

An 18-year-old man with hemoglobin SS-type sickle cell disease presented with acute onset of headaches and horizontal double vision. On examination, he was noted to have a right cranial nerve VI (abducens) palsy. The following day, he also developed an ipsilateral cranial nerve VII (facial) palsy. Neuroimaging was consistent with bony infarction of his clivus secondary to his sickle cell disease and inflammation of the adjacent dura (figure). His presentation and imaging findings are suggestive of transient inflammation of cranial nerves VI and VII as they passed in proximity to the peri-infarct inflammation along the skull base. He received apheresis for elevated sickle hemoglobin levels, and his symptoms resolved within 1 week. His repeat imaging showed resolution of the areas of inflammation and evolution of his bony infarct. His most recent evaluation by neurology at 2 years follow-up was unremarkable, and his symptoms have not recurred.

\section{Author contributions}

J. Wong: case report concept, design and critical revision of content, takes responsibility for the data, analyses and interpretation, conduct of the case report. C. Gambrah-Sampaney: design and critical revision of content. L. Adang: case design and critical revision of the content.

\section{Study funding}

No targeted funding reported.

\section{Disclosure}

The authors report no disclosures relevant to the manuscript. Go to Neurology.org/ $\mathrm{N}$ for full disclosures.

\section{MORE ONLINE}

$\rightarrow$ Teaching slides

links.lww.com/WNL/

A948

*These authors contributed equally to this work.

From the Division of Neurology (J.W., L.A.), Children's Hospital of Philadelphia; University of Pennsylvania School of Medicine (C.G.-S.); and Department of Neurology (C.G.-S.), Hospital of the University of Pennsylvania, Philadelphia.

Go to Neurology.org/N for full disclosures. 


\title{
Neurology
}

\author{
Teaching NeuroImages: Cranial neuropathies following clival infarction \\ Jeremy Wong, Claudia Gambrah-Sampaney and Laura Adang \\ Neurology 2019;93; 1031 \\ DOI 10.1212/WNL.0000000000008070
}

This information is current as of September 2, 2019

Updated Information \&
Services

Subspecialty Collections

Permissions \& Licensing

Reprints including high resolution figures, can be found at: http://n.neurology.org/content/93/10/e1031.full

This article, along with others on similar topics, appears in the following collection(s):

Diplopia (double vision)

http://n.neurology.org/cgi/collection/diplopia_double_vision

Hematologic

http://n.neurology.org/cgi/collection/hematologic

MRI

http://n.neurology.org/cgi/collection/mri

Information about reproducing this article in parts (figures,tables) or in its entirety can be found online at:

http://www.neurology.org/about/about_the_journal\#permissions

Information about ordering reprints can be found online:

http://n.neurology.org/subscribers/advertise

Neurology ${ }^{\circledR}$ is the official journal of the American Academy of Neurology. Published continuously since 1951, it is now a weekly with 48 issues per year. Copyright (O 2019 American Academy of Neurology. All rights reserved. Print ISSN: 0028-3878. Online ISSN: 1526-632X.

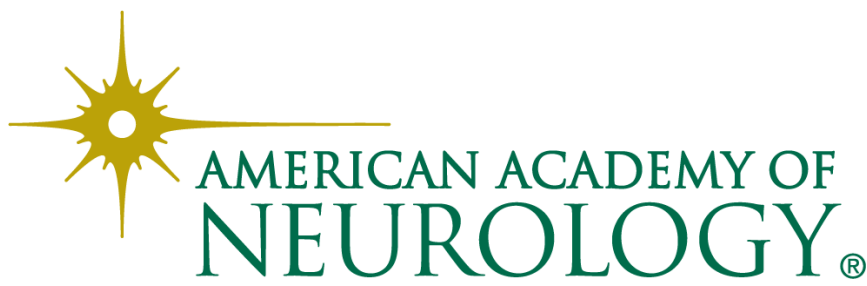

